to the Pre-Cambrian rocks and of Recent fossil bones, and on the mineralogy of natural radioactive substances, are too numerous to itemize. But it is important to mention his numerous popular expositions of radiogeology and the place of geology in human progress, for his facility of lucid presentation rivalled that of the old masters of geology. Davidson's capacity for organization, his ready acceptance of responsibility, and his complete indifference to his own well-being in the course of duty were well known to his colleagues. They became apparent to an international gathering in the success of the recent symposium which he organized in St. Andrews at extremely short notice on behalf of the International Association on the Genesis of Ore Deposits. On the evening of his death he had been busy with proofs of the 50 papers and the proceedings of the meeting. Few men can have lived so full a life and so greatly enjoyed the living of it.

\section{Professor James P. Todd}

Professor TODD, who died on November 10, was appointed lecturer in pharmacy in the Royal Technica] College, Glasgow, in 1921. In 1937 he became the first professor of pharmacy in the United Kingdom, in the same college. From modest beginnings, his work so prospered that he leaves to his successors a great school of biological sciences with more than four hundred students, a large staff qualified in a wide range of scientific disciplines, and eight academic chairs all tracing their foundation directly or indirectly to his inspiration.

A native of Glasgow, James Todd attended Albert Road School and received his early training in the old Glasgow and West of Scotland School of Pharmacy. His military service in the Medical Corps during the First World War in South Africa, India and Iraq gave him an insight into some of the problems of tropical medicine. After the war he resumed his studies and was awarded the qualification of Ph.C. in 1921. In collaboration with the late Professor Ellis, he then helped to establish the first degree course in pharmacy in Britain under the relevant ordinances of Glasgow University. The first students were enrolled in 1924. In the meantime, and often in difficult conditions, he commenced his personal research into the properties of the digitalis drugs which later led to his award of the degree of Doctor of Philosophy by Glasgow University.

His subsequent research always concerned practical problems of medical science and covered a wide field. During the Second World War the Department of Health for Scotland sought his help in preparing pyrogen-free saline infusion fluids, and this led to his contributions in the field of bacterial pyrogens. His work on blood trans. fusion led to the establishment of the West of Scotland Blood Transfusion Service. For many years he was honorary director of this service.

War problems also attracted him to study the treatment of burns (in collaboration with the Medical Research Council, then established at the Royal Infirmary). This work, in turn, brought him into contact with the problems of plastic surgery. The establishment of the chair of bioengineering at Strathelyde can be traced directly to these early contacts with Mr T. Gibson, the plastic surgeon, who first sought his advice in attempting to find means of bringing seience and engineering to bear on the practical work of the operating theatre.

After the war Todd served on a working party set up by the Minister of Food to examine the provision of facilities for the training of young people in the study of the properties and processing of foodstuffs. British vulnerability to food shortage had been highlighted during the war, and after consultations with the experts in this field Todd concluded that this subject merited designation as a scientific discipline in its own right. He established an associateship course (at honours degree level) and described the fiold of study as "Food Science". This was the first course of its kind in the United Kingdom, and is believed to be the first use of this term applied to a degree level course in the world. This course led to the establishment of the chair of food science at Strathclyde in 1958 , and the term food science is now used internationally and on both sides of the Iron Curtain.

For a man who has been the focus of so much initiative in pharmacy, food science, microbiology. pharmacology, pharmaceutical technology, biology and biochemistry, Todd was no academic tycoon. Unassuming in manner, his kindly, simple and tolerant ways disguised a fixity of purpose which was only apparent to those who knew him well, or who had the misfortune to oppose his vision. In these days when it is often difficult to distinguish a professor from a business man, he was one of the last of the great race of university characters. Of course, his unorthodoxy bred opposition. Time and again the ranks would close against him, only to find themselves outflanked by his mental and administrative dexterity. If his opponents were sometimes a little bewildered as to how he achieved his ends, they learned to respect him by his success.

He devoted countless hours to the Pharmaceutical Society, served on expert committees, worked as an examiner and, above all, made behind-the-scenes contributions to the establishment of the University of Strathclyde. This must wait for later appraisal, but it is pleasant to record that in 1964 his services to medicine were recognized by his election as an Honorary Fellow of the Royal College of Physicians and Surgeons, Glasgow. J. HAWTHORN

\section{Professor Douglas McKie}

ONE of Britain's leading historians of science died on August 28, 1967. The son of a Scot, Douglas McKie was born on July 15, 1896, in Tredegar, Monmouthshire, where he was educated at the Grammar School. Intending to be a regular soldier, he entered Sandhurst and served as a lieutenant on the Western Front until he was severely wounded in 1917. He became a chemistry student at University College, London, in 1920, graduated in 1923. and in 1927 obtained his Ph.D. under F. G. Donnan for research on gas adsorption.

Already interested in military history, McKie soon acquired a taste for the history of science, and in 1925 he became a part-time assistant in the new Department of History and Philosophy of Science (as it is now called) at University College, London. A full-time appointment followed, and eventually, from 1957 to 1964 , he was professor and head of the department.

McKie will be chiefly remembered for his studies of seventeenth and eighteenth century theories of heat, com. bustion and related topics; of the men responsible for the advances in this field; and of the institutions to which they belonged. Only his principal works can be mentioned here. In 1935, he published The Discovery of Specific and Latent Heats (with N. H. de V. Heathcote) and Antoine Lavoisier, the Father of Modern Chemistry, which contains a detailed account of Lavoisier's chemical researches. There was thon no British periodical devoted to the history of science; McKie was a founder of Annals of Science, and as its principal editor from 1936 until his death he exercised a great and beneficial influence on the subject. Early volumes contain his masterly series of "Historical Studies in the Phlogiston Theory" (with J. R. Partington) and the first part of his long study of Black's unpublished chemical lectures, completed only in 1967. He was also a foundation member of the Society for the Study of Alchemy and Early Chemistry; his account of the combustion theories of Boyle, Hooke and Mayow is in Volume 1 of its journal, Ambix.

During the 1939-45 war, McKie was attached to the Department of Chemistry of University College, but he found time to publish in 1942 a valuable account of 